\title{
PENGEMBANGAN ALGORITMA IDENTIFIKASI SAWAH PADI BERDASARKAN SPEKTRA FASE PADI (STUDI KASUS: LAMPUNG SELATAN) \\ Paddy Field Identification Algorithm Development Using Spectral Value of Paddy Field (Case Study: South Lampung)
}

\author{
Zulfikar Adlan Nadzirr ${ }^{1,2}$, Nirmawana Simarmata ${ }^{1,2}$, Aliffia $^{1}$ \\ ${ }^{1}$ Program Studi Teknik Geomatika, Institut Teknologi Sumatera, Lampung, Indonesia \\ ${ }^{2}$ Pusat Penelitian Informasi Geospasial, Institut Teknologi Sumatera, Lampung, Indonesia \\ Email Korespondensi: zulfikar.nadzir@gt.itera.ac.id
}

\begin{abstract}
DOI: http://dx.doi.org/10.31314/jsig.v3i1.537
Abstract - Paddy is the staple of Indonesian people. As stated by FAO in 2004, rice, the finished product of paddy, is indeed the principal source of many of the third-world countries. Hence, to gauge the readiness level of a country, one of the parameters is called food security of said country source of food. Yet, assessing food security of a country is not easy, since much of the fields need to be surveyed and counted. This labor-heavy process is nowadays substituted by the usage of remote sensing technology, where one can use a single satellite image to assess the extent of rice fields of one province, or in some case with very-high resolution image, the extent of one regency (kabupaten in Bahasa Indonesia). Kuenzer and Knauer in 2012 has reviewed the usage of remote sensing to identify the rice field, starting from the infancy of remote sensing. One of the main conclusions of above paper is that the process of identifying rice field by means of the rice field's growing progress needs sharpening. Several locations in South Lampung are used to compute a time-dynamic model of rice field spectral signature. This methodology is resulted in a preliminary algorithm of identifying rice field using its growth phases spectral signature, which comes from the results of widely-used NDVI, SAVI, EVI and LAI algorithm. This result is subsequently followed by a field campaign.
\end{abstract}

Keywords: paddy field, identification algorithm, growth phase

\begin{abstract}
Abstrak - Padi merupakan salah satu sumber makanan utama bagi masyarakat Indonesia. Padi dalam siklus hidupnya mempunyai beberapa fase yang dalam konteks penginderaan jauh memiliki karakteristik kurva hamburan yang berbeda-beda, sehingga diperlukan sebuah proses identifikasi dan pengembangan algoritma identifikasi padi yang memperhatikan kurva-kurva hamburan dari setiap fase padi yang ada. Penelitian ini menggunakan algoritma yang sudah umum dipakai oleh kalangan peneliti di bidang vegetasi penginderaan jauh yaitu NDVI (Normalized Difference Vegetation Index), EVI (Enhanced Vegetation Index), SAVI (Soil Adjusted Vegetation Index) dan LAI (Leaf Area Index) sebagai penanda awal dari lokasi vegetasi di Lampung Selatan. Setelah itu lokasi tersebut di-verifikasi dengan survei lapangan untuk mendapatkan letak sebenarnya dari lahan sawah beserta umur/fase dari sawah tersebut. Dari informasi hasil algoritma dan fase padi di lapangan, dibangun sebuah algoritma awalan (preliminary algorithm) identifikasi lokasi sawah padi. Dengan adanya usaha proses pengembangan algoritma identifikasi padi ini, penelitian ini dapat menentukan lokasi-lokasi sawah padi berdasarkan fase-fasenya. Dari lokasi-lokasi ini didukung dan ditambah dengan proses validasi lapangan, didapatkan tingkat kebenaran dari identifikasi.
\end{abstract}

Kata kunci: padi; algoritma identifikasi; fase tumbuh 


\section{PENDAHULUAN}

Padi dan keluarganya merupakan salah satu komoditi persawahan pangan yang utama bagi penduduk Indonesia. Sebagian besar penduduk Indonesia menggunakan nasi sebagai pemenuh gizi dan karbohidrat utama, selain sagu bagi penduduk Indonesia bagian timur. Beras, yang merupakan padi yang sudah dipanen, adalah makanan utama bagi banyak masyarakat dunia ketiga, sesuai dengan FAO pada tahun 2004. Pentingnya beras bagi kehidupan manusia dunia ini dicerminkan dengan jumlah panen padi dalam skala global, yang mencapai 720 juta ton padi, dimana 90\% nya dipanen dari daerah Asia, sesuai dengan Kuenzer \& Knauer pada tahun 2013. Maka dari itu, salah satu indicator bisa bertahannya sebuah negara adalah dengan menghitung tingkat ketahanan pangan (food security) dari sumber makanan negara tersebut. Hanya saja, salah satu masalah utama dari pertanian beras adalah ketidak pastian dari hasil panen, membuat level ketahanan pangan turun seiring dengan berjalannya waktu. Turunnya produksi beras ini sangat timpang apabila dibandingkan dengan tingkat konsumsi beras yang selalu naik, seiring dengan naiknya populasi dunia yang mencapai 9 milyar manusia pada tahun 2050. Untuk menanggulangi masalah ketahanan pangan ini, metode-metode penanaman yang baru dan penanaman lahan sawah padi yang baru merupakan solusi utama (Sakamoto, Cao Van, Kotera, Nguyen Duy, \& Yokozawa, 2009). Hanya saja, berkurangnya lahan subur yang tersedia dan juga berkurangnya ketersediaan air irigasi membuat tingkat ketahan pangan menjadi semakin terganggu, sesuai dengan Gregory, Ingram, \& Brklacich pada tahun 2005.

Sawah adalah sebuah tipe penggunaan lahan yang dalam pengelolaannya memerlukan genangan air. Oleh karena itu, sawah akan selalu memiliki permukaan datar atau yang didatarkan dan dibatas oleh pematang untuk menahan genangan air. Lebih lanjut, berdasarkan sumber air yang digunakan dan keadaan genangannya, sawah dapat dibedakan menjadi 4 jenis yaitu (Sofyan, Wahyunto, Agus, \& Hidayat, 2007): 1) Sawah irigasi, yaitu sawah yang sumber airnya berasal dari tempat lain melalui saluran-saluran yang sengaja dibuat untuk itu. Dibedakan atas sawah irigasi teknis, setengah teknis dan sawah irigasi sederhana; 2) Sawah tadah hujan, yaitu sawah yang sumber airnya tergantung atau berasal dari curah hujan tanpa adanya bangunan-bangunan irigasi permanen. Umumnya terdapat pada wilayah yang posisinya lebih tinggi dari sawah irigasi atau sawah lainnya sehingga tidak memungkinkan terjangkau oleh pengairan. Waktu tanam sangat tergantung kepada datangnya musim hujan; 3) Sawah pasang surut, yaitu sawah yang irigasinya tergantung pada gerakan pasang dan surut serta letaknya di wilayah datar tidak jauh dari laut. Sumber airnya berasal dari air sungai yang karena adanya pengaruh pasang dan surut air dimanfaatkan untuk mengairi melalui saluran irigasi dan drainase; 4) Sawah lebak, yaitu awah yang diusahakan didaerah rawa memanfaatkan naik turunnya permukaan air rawa secara alami, sehingga dalam sistem sawah lebak tidak dijumpai sistem saluran air.

Tanaman padi (Oryza sativa L.) merupakan tanaman semusim dengan morfologi berbatang bulat dan berongga yang disebut jerami. Daunnya memanjang dengan ruas searah batang daun. Pada batang utama dan anakan membentuk rumpun pada fase vegetatif dan membentuk malai pada fase generatif. Air dibutuhkan tanaman padi untuk pembentukan karbohidrat di daun, menjaga hidrasi protoplasma, pengangkutan dan mentranslokasikan makanan serta unsur hara dan mineral. Air sangat dibutuhkan untuk perkecambahan biji. Pengisapan air merupakan kebutuhan biji untuk berlangsungnya kegiatan-kegiatan di dalam biji (Kartasapoetra \& Sutedjo, 1988).

Fase - Fase Pertumbuhan Tiga fase pertumbuhan tanaman padi berdasarkan (Arafah, 2009), diklasifikasikan sebagai berikut: 1) Vegetatif (awal pertumbuhan sampai pembentukan malai); 2) Reproduktif (pembentukan malai sampai pembungaan); 3) Pematangan (pembungaan sampai gabah matang). Keseluruhan organ tanaman padi terdiri dari dua kelompok, yakni organ vegetatif dan organ generatif (reproduktif). Bagian-bagian vegetatif meliputi akar, batang dan daun, sedangkan bagian generatif terdiri dari malai, gabah dan bunga. Dari sejak berkecambah sampai panen, tanaman padi memerlukan 3-6 bulan, yang seluruhnya terdiri dari dua stadia pertumbuhan, yakni vegetatif dan generatif. Fase reproduktif selanjutnya terdiri dari dua, pra berbunga dan pasca berbunga, periode pasca-berbunga disebut juga sebagai periode pemasakan. (Yoshida, 1981) membagi pertumbuhan padi menjadi 3 bagian yakni fase vegetatif, reproduktif, dan pemasakan. Fase vegetatif meliputi pertumbuhan tanaman dari mulai berkecambah sampai dengan inisiasi primordia malai: fase reproduktif dimulai dari inisiasi primordia malai sampai 
berbunga (heading) dan pemasakan dimulai dari berbunga sampai masak panen. Untuk suatu varietas berumur 120 hari yang ditanam di daerah tropik, maka vase vegetatif memerlukan 60 hari, fase reproduktif 30 hari, dan fase pemasakan 30 hari. Stadia reproduktif ditandai dengan memanjangnya ruas teratas pada batang, yang sebelumnya tertumpuk rapat dekat permukaan tanah. Gambar 1 menunjukkan fase pertumbuhan padi.

Penginderaan jauh merupakan salah satu teknologi masa kini yang dapat melakukan pemeriksaan terhadap sebuah lokasi tanpa harus melakukan survei langsung ke lokasi tersebut. Metode penginderaan jauh dapat digunakan sebagai salah satu metode yang cepat dalam tataran waktu dan mendapatkan hasil yang dapat dipercaya (reliable) di berbagai bidang, salah satunya berkenaan dengan system agrikultur padi. Sudah banyak peneliti yang mengajukan dan membahas tentang sistem pengawasan agrikultur padi ini, salah satunya adalah Le Toan, et al., pada tahun 1997 dan Hatfield, Gitelson, Schepers, \& Walthall pada tahun 2008. Dalam beberapa penelitian tersebut, disebutkan beberapa fungsi metode penginderaan jauh dalam pengawasan padi, salah satunya yaitu pada pemetaan dan pengawasan dari lahan pertanian padi itu sendiri, pengawasan terhadap kesehatan dan tingkat pertumbuhan dari padi (yang dimanifestasikan dalam identifikasi fase-fase padi), serta prediksi dan perhitungan perkiraan panen padi per hektar sesuai data dan kondisi yang ada. Berangkat dari fungsi-fungsi penginderaan jauh tersebut, selanjutnya dihasilkan sebuah sistem informasi geografis (SIG) dan juga data-data pendukung lainnya, yang mana dapat menjadi dasar utama dan referensi dalam menyokong sistem manajemen persawahan, manajemen irigasi yang berkelanjutan dan dalam proses pengambilan keputusan di bidang manajemen pangan. Kombinasi hasil dan visualisasi serta aplikasi di atas sudah dijabarkan dalam McVicar di tahun 2005. Hanya saja, proses identifikasi dari tingkat pertumbuhan padi menggunakan metode penginderaan jauh, yang dicirikan dengan progress fase padi masihlah jauh dari kata sempurna, sehingga perlu adanya sebuah usaha nyata dalam meneliti dan mengembangkan algoritma yang lebih sesuai untuk melakukan proses identifikasi padi secara berkesinambungan dan secara kontinu.

Seperti yang sudah dijabarkan di atas, daerah Asia merupakan penghasil padi terbanyak di dunia dengan jumlah $90 \%$ dari total produksi padi. Lokasi Indonesia yang berada di sekitar garis khatulistiwa dan juga mempunyai iklim tropik membuat padi dapat tumbuh secara sehat dan luas. Provinsi Lampung merupakan salah satu sentra produksi padi di Indonesia yang memiliki potensi untuk memajukan pembangunan ekonomi dengan meningkatkan produktivitas padi, dikarenakan pertanian measih menjadi penyerap tenaga kerja terbesar, mencapai 36,52\% angkatan kerja Indonesia, diambil dari data BPS di tahun 2011. Produk Domestik Bruto Indonesia pun masih dipengaruhi oleh hasil pertanian, mencapai $14,7 \%$ dari total PDB Indonesia pada tahun 2011. Di Provinsi Lampung, terdapat luas areal yang besar dan produksi yang cukup tinggi, membuat Lampung mendapat julukan 'lumbung padi Indonesia' dan segala usaha memajukan pertanian di Lampung akan dapat mengangkat perekonomian Lampung pada umumnya.

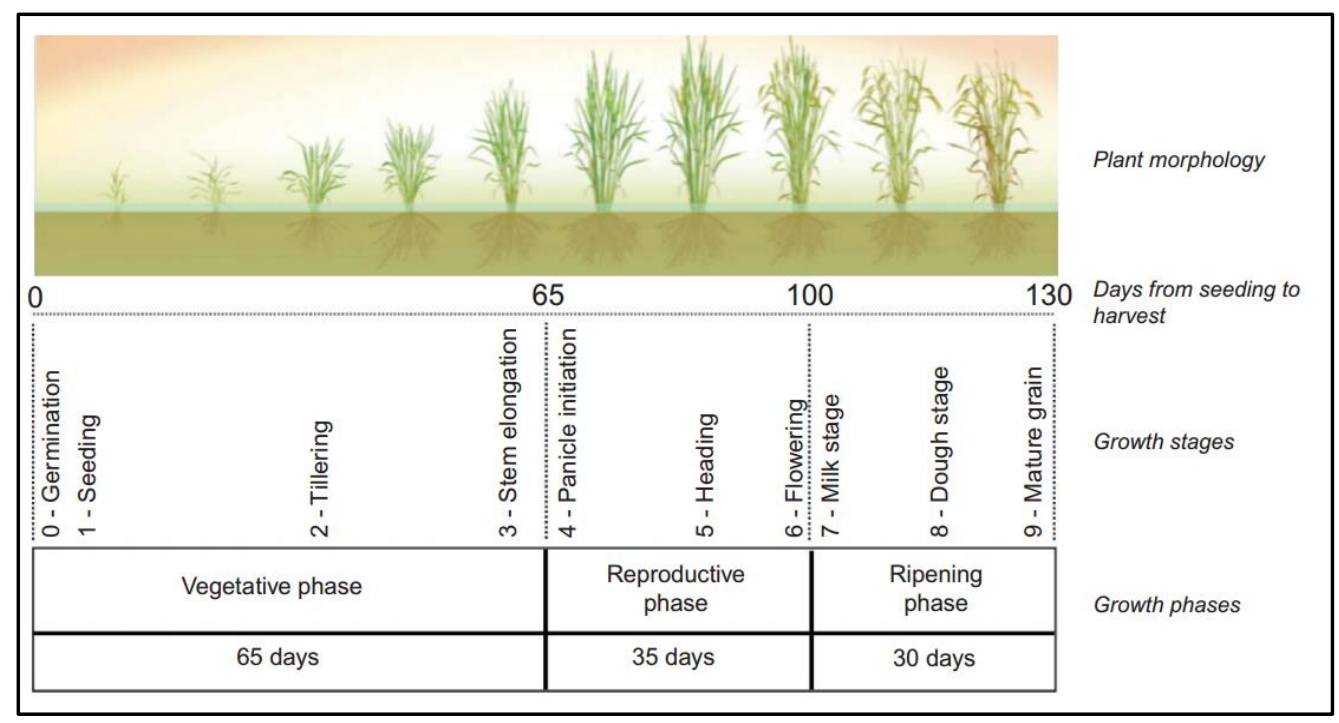

Gambar 1. Fase pertumbuhan padi (Sumber: (Kuenzer \& Knauer, 2013)) 
Hanya saja, di Provinsi Lampung data tepat dan akurat tentang lokasi pertanian padi masih sangatlah kurang, sehingga peluang adanya pengalihan fungsi lahan dari lahan pertanian pangan menjadi pemukiman ataupun industri masih sangat besar. Selain itu, luas panen per hektar dari lahan pertanian padi masih sangat beragam dan belum ada nilai yang pasti dan eksak. Maka dari itu, penelitian ini melakukan pengembangan algoritma dengan memperhatikan fase-fase padi yang ada, sebagai usaha awal dalam menentukan luas sawah padi di Lampung yang lebih pasti dan dapat dipertanggung jawabkan.

\section{METODE DAN DATA}

Lokasi Penelitian

Dalam melakukan penelitian penghitungan algoritma identifikasi padi ini, lokasi yang dipilih adalah Kabupaten Lampung Selatan. Secara geografis Kabupaten Lampung Selatan ini berada pada koordinat $5,734707^{\circ}$ LS $105,593625^{\circ}$ BT. Dalam sistem proyeksi koordinat UTM (Universal Transverse Mercator), wilayah Kabupaten Lampung Selatan terletak pada zona 48 Selatan (48S). Lokasi Kabupaten Lampung Selatan ini tergambar pada Gambar 1 di bawah ini yang diambil dari citra satelit SPOT-6/7. Pemilihan lokasi ini dikarenakan luasnya persawahan padi di Lampung Selatan, mencapai 65 ribu hektar (BPS, 2014).

Penelitian ini menggunakan dua citra satelit SPOT 6/7, yang merupakan sistem satelit observasi bumi yang mencitra secara optis dengan resolusi tinggi dan diopersikan di luar angkasa. Sistem satelit SPOT terdiri dari serangkaian satelit dan stasiun pengontrol denga cangkupan kepentingan yaitu, kontrol dan pemograman satelit, produksi citra, dan distribusinya. SPOT yang merupakan singkatan dari Satellite Pour l'Observtion de la Terre dijalankan oleh Spot Image yang terletak di Prancis. Satelit ini menghasilkan data citra satelit dalam moda pankromatik dengan resolusi spasial 1.5 meter yang terdiri dari 1 band (band pankromatik) serta data citra satelit dalam moda multispektral dengan resolusi spasial 6 meter yang terdiri dari 4 band (band merah, band hijau, band biru, dan band inframerah dekat). Berikut merupakan keterangan dari citra satelit SPOT 6/7 yang digunakan, tertera pada Tabel 1.



Gambar 2. Gambaran lokasi penelitian (Sumber: Citra Satelit SPOT 6/7, 2018) 
Tabel 1. Keterangan dari citra satelit SPOT 6/7 yang digunakan dalam penelitian.

\begin{tabular}{ccccc}
\hline No & Satelit & Mode Akuisisi & Tanggal & Sumber \\
\hline 1 & SPOT-7 & Multispektral & 7 Maret 2018 & LAPAN \\
& & & & \\
2 & SPOT-7 & Multispektral & 1 September 2018 & LAPAN \\
\hline
\end{tabular}

\section{Tahapan Penelitian}

Penelitian ini adalah penelitian kuantitatif yang memanfaatkan data spektral dari lokasi yang ada di beberapa titik di area penelitian sebagai dasar dalam perhitungan algoritma awal ídentifikasi sawah padi menggunakan citra satelit. Tahapan pertama dari penelitian ini adalah pemrosesan awal yaitu koreksi geometrik menggunakan proses rektifikasi citra ke peta (image to map) dan radiometrik agar nilai yang tersimpan pada setiap piksel di citra satelit sesuai dengan keadaan nyata, yaitu TOA (Top of the Atmosphere) Reflectance. Tahapan ini dilanjutkan oleh tahapan yang kedua, yaitu identifikasi awal lokasi-lokasi sawah padi menggunakan algoritmaalgoritma yang jamak digunakan dalam proses identifikasi vegetasi. Tahapan kedua ini menggunakan NDVI (Normalized Digital Vegetation Index), SAVI (Soil Adjusted Vegetation Index), LAI (Leaf Area Index) dan EVI (enhanced Vegetation Index). NDVI adalah sebuah algoritma yang mengutilisasi kanal gelombang inframerah dekat (NIR) dan gelombang terdekat (visible) warma merah (Red). Rumus dari algoritma NDVI ini dijabarkan di Rumus (1) di bawah ini (Tucker, 1979).

$$
\mathrm{NDVI}=\frac{(\mathrm{NIR}-\mathrm{Red})}{(\mathrm{NIR}+\mathrm{Red})}
$$

Selanjutnya, SAVI adalah sebuah algoritma yang dikembangkan sebagai pengganti NDVI yang memasukkan faktor kecerahan dari permukaan tanah sehingga hasil identifikasi terbebas dari cerah atau gelapnya sebuah permukaan tanah tempat vegetasi tersebut berada. Rumus dari algoritma SAVI terdapat pada Rumus (2), dengan tambahan L yaitu sebuah konstanta pengubah kanopi dengan nilai sebesar 0,5 (Huete, 1988).

$$
\mathrm{SAVI}=\frac{(1+\mathrm{L})(\mathrm{NIR}-\mathrm{Red})}{(\mathrm{NIR}+\mathrm{Red}+\mathrm{L})}
$$

Algoritma ketiga yang digunakan adalah algoritma bernama LAI, sebuah penanda relasi antara besar area daun dengan area di sekitar daun tersebut. Menurut (Risdiyanto \& Setiawan, 2007), rumus dari LAI adalah sebagai berikut, di Rumus (3), dengan I adalah radiasi pada lapisan dengan ketinggian tertentu dalam kanopi, $\mathrm{I}_{0}$ adalah radiasi di permukaan kanopi dan $\mathrm{k}$ sebagai koefisien pemadaman yang berkisar antara 0,3 sampai 1,0 .

$$
\mathrm{LAI}=\left(\left(\operatorname{Ln} \frac{\mathrm{I}}{\mathrm{I}_{0}}\right) /(-\mathrm{k})\right)
$$

Keempat, algoritma yang digunakan adalah EVI, yang merupakan sebuah algoritma identifikasi vegetasi yang khusus dirancang untuk mengedepankan sinyal vegetasi dengan sesitivitas lebih baik di area dengan konsentrasi biomassa tinggi melalui pemisahan sinyal kanopi dan pengurangan pengaruh atmosfer. Algoritma ini menggunakan dua kanal yaitu kanal NIR dan kanal Merah, seperti tertulis pada Rumus (4) (Huete, et al., 2002)

$$
\mathrm{EVI} 2=2.5 *((\mathrm{NIR}-\mathrm{Red} /(\mathrm{NIR}+2.4 * \operatorname{Red}+1))
$$

Keempat algoritma tersebut dijalankan pada dua citra satelit SPOT-7 untuk mendapatkan 
identifikasi awal lokasi vegetasi, dalam hal ini adalah sawah padi. Tahapan ketiga dari penelitian ini adalah proses terjun ke lapangan untuk mengetahui kebenaran fase-fase padi yang terekam pada citra satelit SPOT7, sekaligus sebagai perekaman data lokasi dari sawah padi di Kabupaten Lampung Selatan. Setelah itu, proses dilanjutkan dengan perhitungan algoritma identifikasi padi berdasarkan fase padi, di mana fase vegetatif diberi nilai 1, fase reproduktif diberi nilai 2 dan fase pematangan diberi nilai 3. Pemberian nilai ini dijadikan dasar dalam perhitungan algoritma identifikasi sesuai dengan sawah padi, yaitu dengan menggunakan metode regresi linier untuk mendapatkan rumus dari nilai-nilai identifikasi dari algoritma awal (NDVI. SAVI, LAI dan EVI) yang disesuaikan dengan parameterisasi model dari (Passaro, Nadzir, \& Quartly, 2018). Model linier dari hasil perhitungan inilah yang digunakan sebagai algoritma awal identifikasi sawah padi berdasarkan spektra dari setiap fasenya. Terakhir, dilakukan analisis statistika singkat mengenai algoritma yang dihasilkan, sebagai indikasi kebenaran dari algoritma awal identifikasi sawah padi berdasarkan spektra fase tersebut.

\section{HASIL DAN PEMBAHASAN \\ Pre-Processing (Koreksi Geometrik dan Radiometrik)}

Proses koreksi geometrik telah dilakukan menggunakan data Peta RBI (Rupa Bumi Indonesia) (Badan Informasi Geospasial, 2017) menggunakan lima titik GCP (Ground Control Points) yang menghasilkan tingkat akurasi sebesar 0,3 piksel, yang mana sebesar 1,8 meter. Nilai ini masih masuk ke dalam toleransi nilai koreksi geometrik yaitu 1 piksel atau 6 meter pada (Nadzir, Jaelani, \& Sulaiman, 2016).

Proses selanjutnya yang dilakukan adalah koreksi radiometrik untuk menghilangkan efek atmosfer, sehingga didapatkan nilai reflektan di puncak atmosfer (top of atmosphere) sebagai hasil dari koreksi radiometrik tersebut. Data lalu melalui proses penghilangan (masking) awan dan badan air khususnya lautan agar tidak mengganggu proses identifikasi selanjutnya.

\section{Identifikasi Awal menggunakan NDVI, SAVI, LAI dan EVI dan Penentuan Lokasi Survei}

Setelah melalui tahap pre-processing, data lalu diolah menggunakan algoritma NDVI di Rumus (1) yang mendapatkan nilai di antara - 1 sampai 1 dengan nilai kisaran umum di vegetasi hijau yaitu 0,2 sampai 0,8. Nilai indeks NDVI yang didapat memiliki rata-rata sebesar 0,199. Histogram dan Peta di Gambar 3(a), Gambar 3(b) dan Gambar 3(c) menunjukkan bahwa nilai NDVI dominan pada wilayah Lampung Selatan pada Maret 2018 dan September 2018 adalah 0,2 sampai 0,4 yang mana dapat diartikan bahwa pada waktu tersebut masih banyak lahan vegetasi hijau yang tidak terlalu lebat di area Lampung Selatan. Kedua, dilanjutkan dengan melakukan perhitungan menggunakan algoritma SAVI di Rumus (2) dengan kisaran nilai pada -0,07 sampai 0,08 dengan nilai rerata pada citra satelit SPOT-7 area Lampung Selatan di bulan Maret 2018 dan September 2018 yaitu 0,007. Pada Gambar 4(a), Gambar 4(b) dan Gambar 4(c) terlihat bahwa konsentrasi data ada pada kisaran yang sangat kecil yaitu antara 0,00 sampai 0,01 . Hal ini terjadi dikarenakan adanya kecenderungan dari hasil algoritma SAVI untuk menjadi sensitif terhadap perubahan kanopi tanpa terpengaruh oleh cerah atau gelapnya permukaan tanah. Ketiga, menggunakan algoritma LAI dari Rumus (3) didapatkan nilai yang lebih kecil rentangnya, yaitu dari -0,23 sampai 0,82 dengan rerata sebesar -0,09. Hal ini ditunjukkan dari Gambar 5(a), Gambar 5(b) dan Gambar 5(c). Selanjutnya, menggunakan indeks keempat yaitu EVI dari Rumus (4) yang akan memiliki rentang antara -1 sampai 1, didapatkan hasil rerata 0,006 . Hasil ini adalah hasil koreksi dari hasil algoritma NDVI yang berkurang akibat kandungan aerosol atmosfer dan digunakan sebagai hasil yang lebih tajam dibandingkan dengan NDVI dengan mengalikan 2,5 lalu dibagi dengan 2,4 ditambah 1 untuk koreksi kanopi, sebagai pengganti nilai L pada rumus SAVI di Rumus (2). Gambar 6(a), Gambar 6(b) dan Gambar 6(c) yang menunjukkan hasil EVI memperlihatkan bahwa hasil EVI lebih halus secara visual daripada nilai NDVI, SAVI dan LAI. Selain itu, interval yang kecil membuat EVI sangat sensitif terhadap perubahan kecil pada kanopi vegetasi hijau, yang sangat relevan dengan perubahan nilai spektral dari setiap fase-fase penumbuhan padi. 
Nadzir, Z.A., dkk., 2020 Jurnal Sains Informasi Geografi [JSIG], 3(1):23-36, ISSN 2614-1671

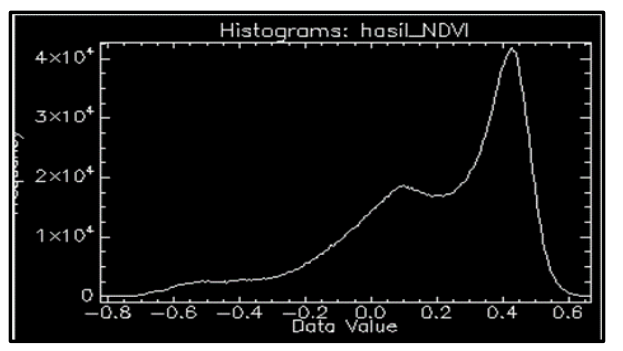

(a)

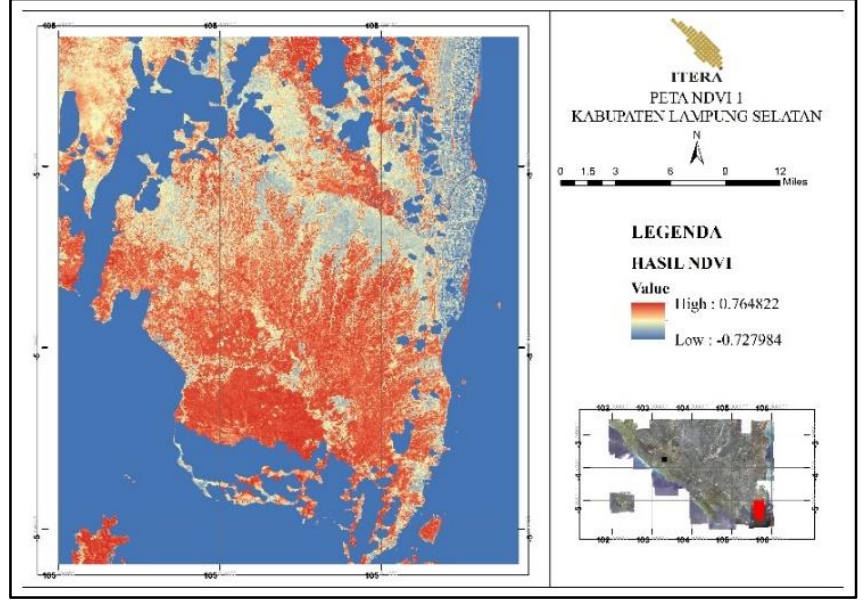

(b)



(c)

Gambar 3. Hasil Algoritma NDVI pada Citra satelit SPOT-7 (Sumber: Analisis Penulis, 2018) 
Nadzir, Z.A., dkk., 2020 Jurnal Sains Informasi Geografi [JSIG], 3(1):23-36, ISSN 2614-1671



(a)

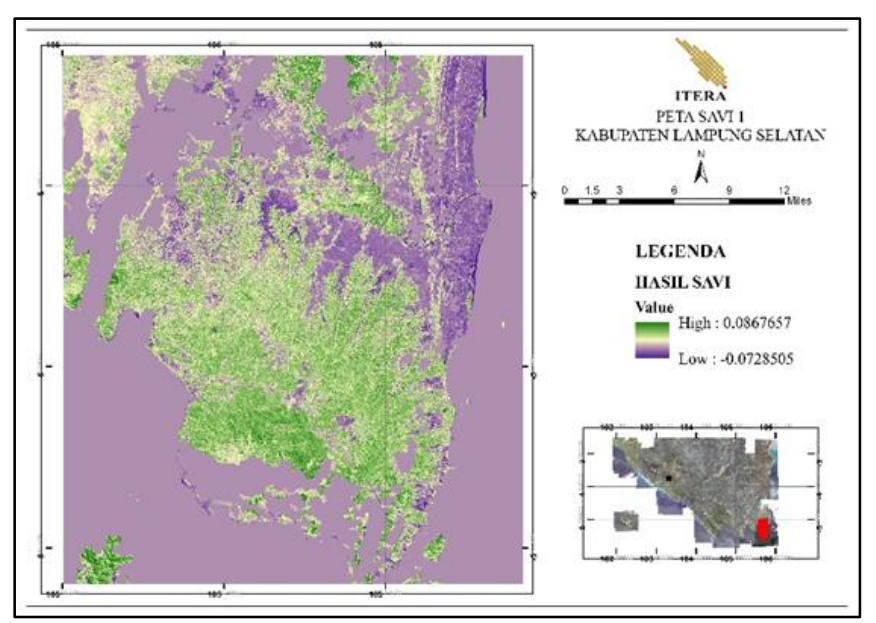

(b)

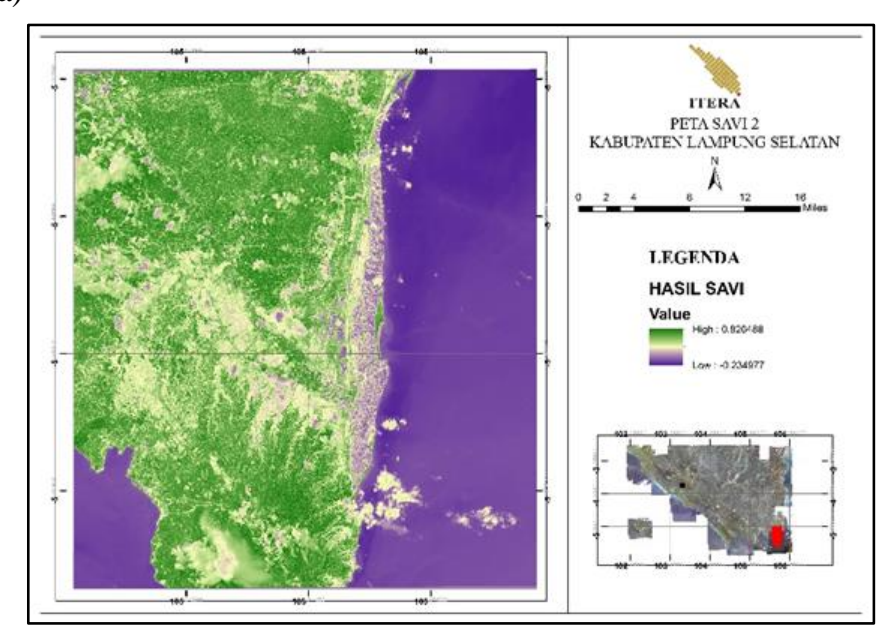

(c)

Gambar 4. Hasil Algoritma SAVI pada Citra satelit SPOT-7 (Sumber: Analisis Penulis, 2018) 




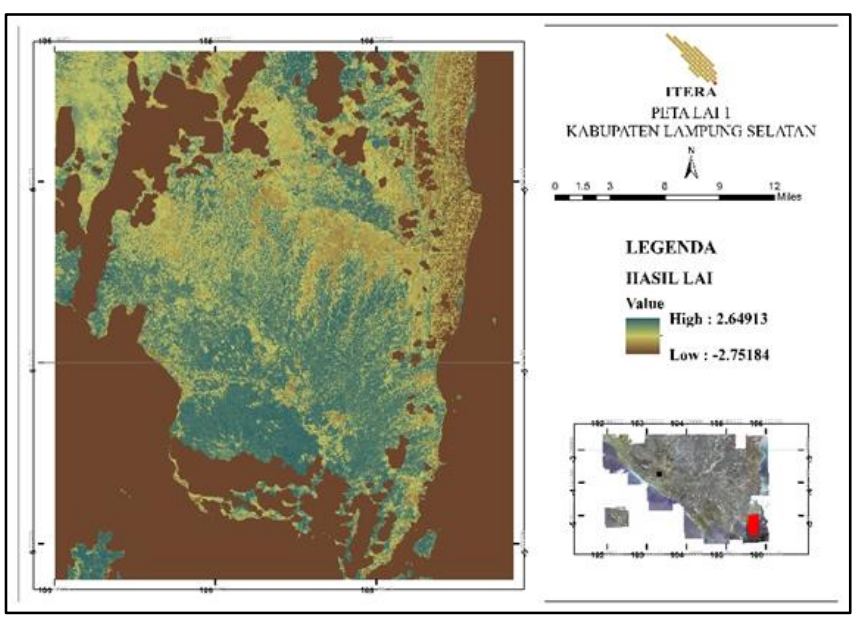

(b)

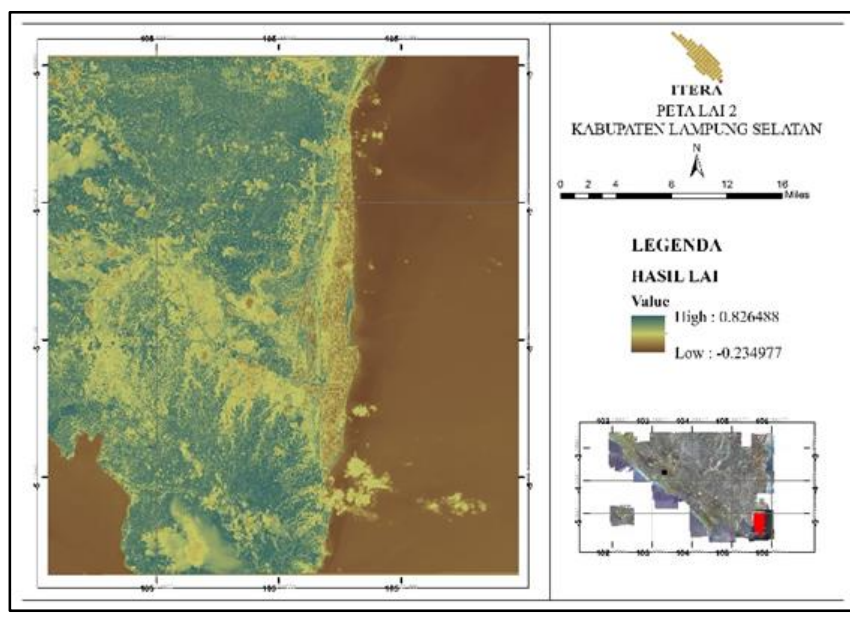

(c)

Gambar 5. Hasil Algoritma LAI pada Citra satelit SPOT-7 (Sumber: Analisis Penulis, 2018) 
Nadzir, Z.A., dkk., 2020 Jurnal Sains Informasi Geografi [JSIG], 3(1):23-36, ISSN 2614-1671



(a)

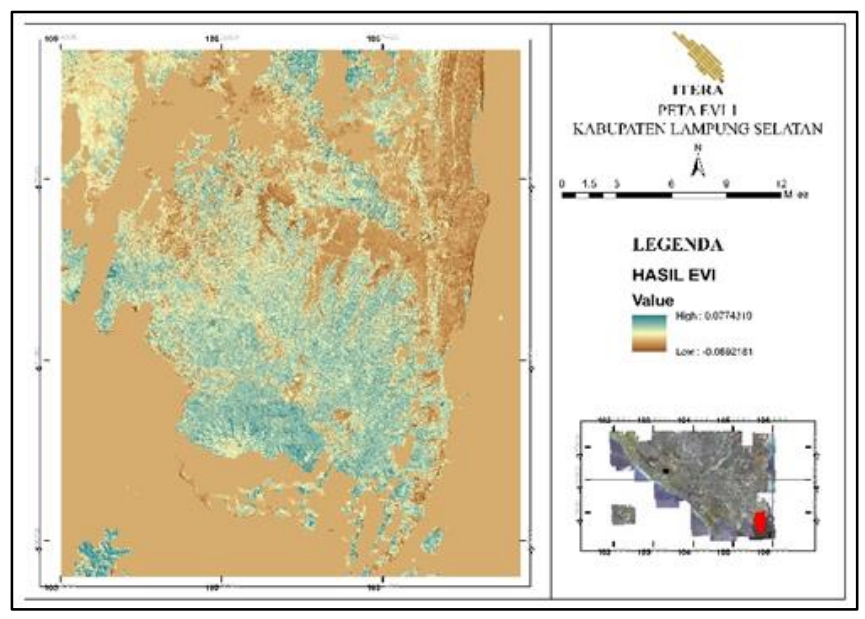

(b)

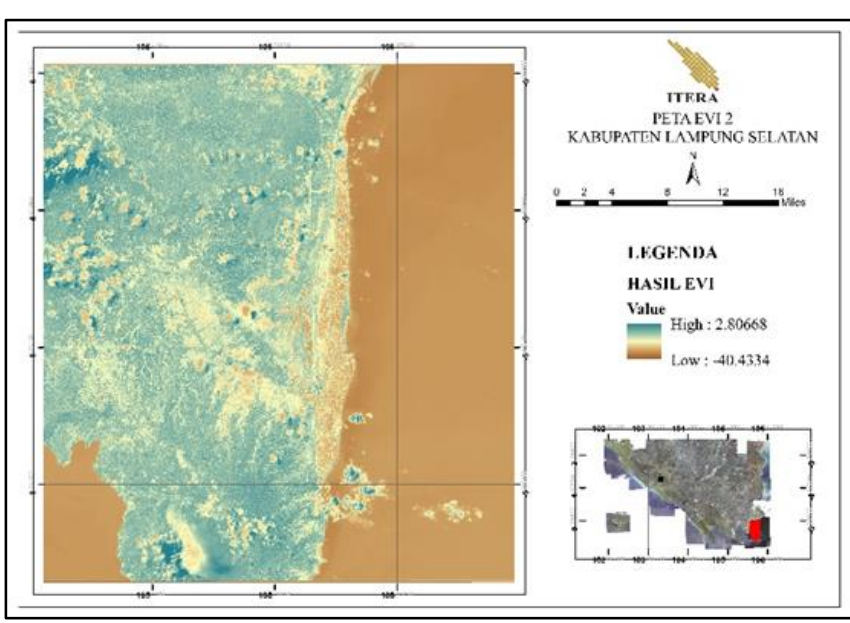

(c)

Gambar 6. Hasil Algoritma EVI pada Citra satelit SPOT-7 (Sumber: Analisis Penulis, 2018) 
Berangkat dari hasil identifikasi menggunakan empat indeks di atas (NDVI, SAVI, LAI dan EVI) ditentukan 50 lokasi secara acak di Provinsi Lampung Selatan untuk ditinjau kebenarannya sebagai sebuah lahan sawah padi dan apabila merupakan sawah padi bagaimana umur dari sawah padi tersebut, sebagai dasar dan masukan awal dari pembuatan algoritma yang akan dibangun. Pada Tabel 2 ditunjukkan 12 lokasi dari 50 lokasi survey tersebut, dalam sistem proyeksi peta UTM (Universal Traverse Mercator) Zona 48 Selatan.

Tabel 2. 12 Lokasi Survey Lapangan dari Hasil Identifikasi Awal (sumber: Analisis Penulis, 2018).

\begin{tabular}{llllll} 
No & X (meter) & Y (meter) & No & X (meter) & Y (meter) \\
\hline 1 & 578089,4 & 9385592 & 7 & 569669,4 & 9381172 \\
2 & 579809,4 & 9382352 & 8 & 571269,4 & 9383092 \\
3 & 576749,4 & 9382452 & 9 & 575129,4 & 9380452 \\
\hline 4 & 575489,4 & 9383552 & 10 & 576849,4 & 9380872 \\
\hline 5 & 579489,4 & 9382052 & 11 & 578569,4 & 9380932 \\
\hline 6 & 579109,4 & 9384972 & 12 & 579489,4 & 9381552 \\
\hline
\end{tabular}

\section{Survey Lapangan}

Menggunakan 50 lokasi yang tergambarkan pada Tabel 2, dilakukan survey ke daerah Lampung Selatan pada bulan September 2018 yang merekan umur dari sawah padi tersebut dan luasan dari sawah padinya serta mendokumentasikan prosesnya. Dari survei, didapat 12 lokasi yang diteliti dengan lengkap yang sudah mewakili fase-fase pertumbuhan padi (vegetatif, reproduktif dan pematangan). Tabel 3 menunjukkan keterangan dari 12 titik tersebut.

Tabel 3. Hasil Survey Lapangan (sumber: Analisis Penulis, 2018).

\begin{tabular}{lcclc}
\hline Titik & Lokasi & Sawah Fase & Luas & Keterangan \\
\hline S01 & Kota Dalan sidomulyo & Reproduktif & $0,3 \mathrm{Ha}$ & - \\
S02 & Gunung Terang, Kalianda & Bekas Sawah & $1 \mathrm{Ha}$ & - \\
S03 & Agom, Kalianda & Lahan Jagung & $1 \mathrm{Ha}$ & Ada sawah padi luas di seberang \\
\hline S04 & Kalianda & Reproduktif & $1 \mathrm{Ha}$ & Ada sawah padi luas di Selatan \\
\hline S05 & Tajimalela, Kalianda & Reproduktif & $1 \mathrm{Ha}$ & - \\
\hline S06 & Negeri Pandan, Kalianda & Vegetatif & $0,1 \mathrm{Ha}$ & Di sebelah timur banyak sawah tua \\
S07 & Pasuruan, Penengahan & Vegetatif & $3 \mathrm{Ha}$ & Sekeliling area banyak sawah \\
\hline S08 & Tetaan, Penengahan & Vegetatif & $3 \mathrm{Ha}$ & Diantara jalan tol \\
\hline S09 & Taman Sari, Ketapang & Vegetatif & $2 \mathrm{Ha}$ & Merupakan areal persawahan luas \\
\hline S10 & Ketapang & Vegetatif & $50 \mathrm{Ha}$ & Kering \\
\hline S11 & Bangun Rejo, Ketapang & Reproduktif & $1 \mathrm{Ha}$ & Kanan-kiri jalan \\
\hline S12 & Taman Baru, Penengahan & Pemataangan & $2 \mathrm{Ha}$ & Sudah mulai merunduk \\
\hline
\end{tabular}




\section{Perhitungan Algoritma Identifikasi Sawah Padi}

Seluruh data lapangan yang sudah didapatkan berjumlah 12 tersebut lalu dicocokkan dan dicatat nilai dari NDVI, SAVI, LAI dan EVI nya dari Citra 1 (Maret 2018) dan Citra 2 (September 2018). Setelah itu, diberikan nilai sesuai dengan fasenya, dalam hal ini karena selisih waktu antara citra tepat 6 bulan yaitu umur rata-rata sawah padi, maka dari dua citra tersebut dianggap mengalami fase yang sama. Tabel 4 menampilkan hasil pencatatan nilai 4 algoritma (NDVI, SAVI, LAI dan EVI). Dalam tabel ini, titik S01, S05 dan S09 dihilangkan karena tidak termasuk dalam ruang lingkup citra yang telah diproses, membuat data hanya tersisa 10 saja. Selain itu, titik S02 dan titik S03 tidak dimasukkan dalam pemrosesan perhitungan algoritma karena bukan merupakan sawah padi. Proses perhitungan algoritma ini menggunakan parameterisasi berupa regresi linier yang terbagi menjadi 5 bagian, yaitu algoritma hasil penggabungan nilai dari 4 algoritma awal dan algoritma berdasarkan masing.masing dari nilai algoritma awal.

Tabel 4. Pemberian nilai 4 algoritma untuk hasil Survey Lapangan (sumber: Analisis Penulis, 2018).

\begin{tabular}{|c|c|c|c|c|c|c|c|c|c|}
\hline \multirow{2}{*}{ Titik } & \multirow{2}{*}{$\begin{array}{c}\text { Nilai } \\
\text { Y }\end{array}$} & \multicolumn{4}{|c|}{ Citra 1} & \multicolumn{4}{|c|}{ Citra 2} \\
\hline & & SAVI & NDVI & LAI & EVI & SAVI & NDVI & LAI & EVI \\
\hline S01 & - & - & - & - & - & 0,532 & 0,665 & 2,052 & 0,600 \\
\hline S02 & - & 0,037 & 0,532 & 1,806 & 0,021 & 0,335 & 0,491 & 1,334 & 0,401 \\
\hline S03 & - & 0,033 & 0,528 & 1,791 & 0,020 & 0,463 & 0,609 & 1,779 & 0,524 \\
\hline S04 & 2 & $-0,003$ & $-0,059$ & $-0,333$ & $-0,002$ & 0,484 & 0,620 & 1,940 & 0,569 \\
\hline S05 & - & 0,029 & 0,541 & 1,838 & 0,017 & 0,356 & 0,485 & 1,577 & 0,469 \\
\hline S06 & 1 & 0,021 & 0,413 & 2,376 & 0,012 & 0,496 & 0,621 & 1,923 & 0,564 \\
\hline S07 & 1 & $-0,012$ & $-0,148$ & $-0,652$ & $-0,007$ & 0,232 & 0,353 & 0,834 & 0,263 \\
\hline S08 & 1 & $-0,004$ & $-0,080$ & $-0,409$ & $-0,002$ & 0,186 & 0,288 & 0,717 & 0,231 \\
\hline S10 & 1 & 0,001 & 0,011 & $-0,079$ & 0,000 & 0,099 & 0,205 & 0,217 & 0,093 \\
\hline S11 & 2 & $-0,012$ & $-0,181$ & $-0,772$ & $-0,007$ & 0,278 & 0,431 & 0,997 & 0,308 \\
\hline $\mathrm{S} 12$ & 3 & 0,007 & 0,124 & 0,331 & 0,004 & 0,540 & 0,651 & 2,282 & 0,663 \\
\hline
\end{tabular}

Pada perhitungan algoritma pertama yaitu penggabungan seluruh nilai, didapatkan nilai koefisien pengali sebesar 0,167 dan offset sebesar 1,529 dengan nilai standar error sebesar 0.001. Nilai error standar ini merupakan penanda dari tingkat akurasi model yang dihasilkan, tergambar pada Rumus (5) dan Gambar 7(a). Pada pengolahan berdasarkan nilai NDVI, didapatkan nilai koefisien pengali sebesar 0,694 dengan offset sebesar 1,455 dan error standar sebesar $-0,018$, tergambar pada Rumus (6) dan Gambar 7(b). Selanjutnya, pada nilai dari hasil SAVI, didapatkan koefisien pengali sebesar 0,685 dengan offset sebesar 1,466 dan standar error sebesar -0,039, terlihat pada Rumus (7) dan Gambar 7(c). Nilai keempat adalah nilai yang diambil dari algoritma LAI, dengan koefisien sebesar 0,108 dan offset sebesar 1,498 dan error standar sebesar -0.05 dengan keterangan Rumus (8) dan Gambar 7(d). Kelima, nilai yang didapatkan dari hasil algoritma EVI adalah koefisien pengali sebesar 0,841 dengan offset sebesar 1,491 dengan error standar senilai -0,002, tergambar pada Rumus (9) dan Gambar 7(e).

Dari seluruh algoritma yang dihasilkan didapatkan bahwa algoritma dari perhitungan keseluruhan merupakan algoritma dengan nilai error standar yang paling kecil, yaitu sebesar 0,001 .

$$
\mathrm{AIP}_{1}=0,167 * \mathrm{X}+1,529
$$




$$
\begin{aligned}
& \mathrm{AIP}_{2}=0,694 * \mathrm{X}+1,455 \\
& \mathrm{AIP}_{3}=0,685 * \mathrm{X}+1,466 \\
& \mathrm{AIP}_{4}=0,108 * \mathrm{X}+1,498 \\
& \mathrm{AIP}_{5}=0,841 * \mathrm{X}+1,491
\end{aligned}
$$

\section{KESIMPULAN}

Berdasarkan penelitian yang dilaksanakan, didapatkan bahwa empat algoritma awal (NDVI, SAVI, LEI dan EVI) dapat menjadi algoritma tumpuan dalam menentukan algoritma baru berdasarkan fase padi yang telah dilakukan, di mana gabungan dari keempatnya merupakan algoritma lanjutan yang paling baik di antara 5 opsi algoritma lanjutan lainnya dengan nilai error standar sebesar 0,001. Algoritma ini akan lebih baik apabila nanti dilakukan proses validasi dan pengembangan dengan menambahkan pustaka spektra yang diambil menggunakan field spectrometer yang lebih tertata, terstruktur dan menjadikan pengembangan algoritma ini lebih bebasis pada spektra Padi sesuai fasenya (vegetatif, reproduktif dan pematangan).

\section{UCAPAN TERIMA KASIH}

Penulis mengucapkan terima kasih yang sebesar-besarnya atas program Hibah Penelitian Institut Teknologi Sumatera Tahun 2018 dengan nomor kontrak 134ad/IT9.C1/PP/2018 yang telah menjadikan penelitian ini terwujud dan berjalan dengan baik.

\section{DAFTAR PUSTAKA}

Arafah. (2009). Pengelolaan dan Pemanfaatan Padi Sawah. Bogor: Bumi Aksara.

Badan Informasi Geospasial. (2017). Peta Rupa Bumi Indonesia. Indonesia.

BPS. (2011). Indonesia Dalam Angka. Jakarta.

FAO. (2004). Proceedings of the FAO Rice Conference - Rice is Life. International Rice Commission Newsletter. Rome.

Gregory, P., Ingram, J. S., \& Brklacich, M. (2005). Climate Change and Food Security. Philosophical Transactions of the Royal Society Biological Sciences, 2139-2148.

Hatfield, J. L., Gitelson, A., Schepers, J., \& Walthall, C. L. (2008). Application of Remote Sensing for Agronomic Decisions. Agronomy Journal, S-117 - S-131.

Huete, A. (1988). A soil-adjusted vegetation index (SAVI). Remote Sensing of Environment, 259309.

Huete, a., Didan, K., Miura, T., Rodriguez, E., Gao, L., \& Ferreira, L. G. (2002). Overview of the Radiometric and Biophysical performance of the MODIS Vegetation Indices. Remote Sensing of Environment, 195-213.

Kartasapoetra, A., \& Sutedjo, M. M. (1988). Budidaya Tanaman Padi di Lahan Rawa Pasang Surut. Jakarta: PT Bina Angkasa.

Kuenzer, C., \& Knauer, K. (2013). Remote Sensing of Rice Crop Areas. International Journal of Remote Sensing, 2101-2139.

Le Toan, T., Ribbes, F., Wang, L.-F., Floury, N., Ding, K. H., \& Kong, J. F. (1997). Rice Crop Mapping and Monitoring using ERS-1 Data Based on Experiment and Modelling Results. IEEE Geoscience and Remote Sensing, 41-56.

McVicar, T. (2005). Remote Sensing of Irrigated Crop Types and Its applications to Regional Water Balance Estimation. Canberra: RICE CRC Final Research Report.

Nadzir, Z., Jaelani, L. M., \& Sulaiman, A. (2016). Estimasi Tinggi Gelombang Laut menggunakan Citra Satelit ALOS-PALSAR, Studi Kasus Perairan Pulau Poteran, Sumenep. Junal Geosaintek, 173-184.

Passaro, M., Nadzir, Z., \& Quartly, G. (2018). Improving the precision of sea level data from satellite altimety with high-frequency and regional sea state bias corrections. Remote Sensing of Environment, 245-254.

Risdiyanto, I., \& Setiawan, R. (2007). Metode Neraca Energi Untuk Perhitungan Indeks Luas 
Daun Menggunakan Data Citra satelit Multispektral. Jurnal Agromet Indonesia, 27-38.

Sakamoto, T., Cao Van, P., Kotera, A., Nguyen Duy, K., \& Yokozawa, M. (2009). Detection of Yearly Change in Farming Systems in Vietnamese Mekong Delta from MODIS Time Series Imagery. Japan Agriculture Research Quarterly, 173-185.

Sofyan, R., Wahyunto, Agus, F., \& Hidayat, H. (2007). Evaluasi Kesesuaian Lahan dengan Contoh Peta Arahan Penggunaan Lahan Kabupaten Aceh Selatan. Bogor: Balai Penelitian Tanah dan World Agroforestry Center.

Tucker, C. (1979). Red and Photograhic Infrared Linear combination for Monitoring Vegetation. Remote Sensing of Environment, 127-150.

Yoshida, S. (1981). Fundamental of Rice Crop Science. Los Banos: IRRI. 